\title{
Measurements of water temperature in fountains as an indicator of potential secondary water pollution caused by Legionella bacteria
}

\author{
Joanna Bąk $^{1, *}$ \\ ${ }^{1}$ CUT, Institute of Water Supply and Environmental Protection, 31-155 Cracow, 24 Warszawska \\ Street, Poland
}

\begin{abstract}
At high air temperatures persisting for a long time, water temperature in the fountains may also increase significantly. This can cause a sudden and significant increase in Legionella bacteria, which results in secondary water contamination. This phenomenon with water air aerosol generated by fountains can be very dangerous for people. During the test, water temperature measurements in fountains in Poland were made. These research tests was conducted in the spring and summer. The research was conducted in order to determine whether there is a possibility of growth of Legionella bacteria. One of the aims of the study was to determine what temperature range occurs in the fountains and how the temperature changes in the basin of the fountain and when the highest temperature occurs. Single temperature measurements were made and also the temperature distribution was measured during daylight hours. The water temperature in most cases was greater than $20^{\circ} \mathrm{C}$, but in no case exceed $26^{\circ} \mathrm{C}$. The paper presents also the review about the effect of water temperature on the presence and bacterial growth. The study confirmed the existence of the risk of increasing the number of bacteria of the genus Legionella in the water in the fountains.
\end{abstract}

\section{Introduction}

Not only the excessive quantity or the water deficit are dangerous. The presence in water of certain elements and compounds and selected microorganisms can also have a negative impact on the health and life of humans. Contaminated water is also harmful to the environment and living organisms. Public fountains can be potential sources of Legionella bacteria. The quality of water circulating in urban fountains is extremely important. Due to the formation of water-air aerosols in their vicinity, particular attention should be paid to the presence of Legionella in the water, as the inhalation of the bacteria is by inhalation. Infected aerosol remains unsafe up to $1 \mathrm{~km}[1]$.

In drinking water used by consumers at tap water supply points may be small amounts of Legionella bacteria. Circles of public fountains are usually supplied with or supplemented with drinking water. In Polish regulations, these bacteria appear several

* Corresponding author: jbak@pk.edu.pl 
times. The Ordinance of the Minister of Health of 13 November 2015 on the quality of water intended for human consumption [2] reiterates the establishment of requirements for their quantity in warm water that was already present in the previous regulation (The Ordinance of the Minister of Health of 29 March 2007 on the quality of water intended for human consumption, [3]). The requirements for these microorganisms also appear in the Ordinance of the Minister of Health concerning the quality of water in swimming pools [4]. This issue is particularly important because of the lack of requirements for the quality control of water in fountains' basins in terms of presence Legionella bacteria.

In cases where there are no favourable conditions for the development of Legionella bacteria in the building, there are no significant risks. Problems begin to appear when certain conditions are present, including increased cold water temperatures or reduced hot water temperatures. Issues related to the development of Legionella bacteria in hot and cold water systems are already described in the technical literature.

Another potential source of Legionella bacteria, which may be fountains, has been observed. It was due to the very hot summer of 2015 in Poland. During sunny days with a high temperature for a considerable part of the day, the water temperature in the fountains may also be significantly elevated. This can cause a sudden and significant increase in the number of Legionella bacteria. These bacteria in a fountain that produces water - air aerosols can be very dangerous to humans.

The aim of the study was to assess whether there is a risk of potential secondary contamination of water in fountains caused by the sudden growth of Legionella bacteria. The factor that made the assessment was the water temperature which is one of the most important factors determining the development of these bacteria.

\subsection{Water quality in fountains in Poland}

Water quality in fountains in Poland is not a priority issue. Although voivodship sanitaryepidemiological stations issue warnings to avoid bathing in fountains and contact with water coming from them and explaining what might be a threat, quality of water in fountains is not constantly monitored. Water supply is subject to constant control, water quality in swimming pools is also checked, but there is no obligation in Poland to maintain constant monitoring of water in urban fountains.

The quality of water in fountains is sporadically discussed in national scientific articles[5-8]. The research conducted by [7] analysed not only water quality, but also air around the fountains in Warsaw. Some of the selected fountains contained mesophilic bacteria, coliform bacteria, Pseudomonas sp., macroscopic fungi and mannitol - positive staphylococcus. Microorganisms whose presence was examined were found in at least one of the fountains. In another work [6], water from Poznan city fountains was inspected at different times of the year. The presence of mesophilic, psychrophilic and coliform bacteria was detected there. In the remaining articles mentioned, inner fountains or fountains in another country were checked. It should be noted that in the cited studies of fountain waters in two large cities of Poland, the presence of mesophilic bacteria was found in which Legionella could be present.

\subsection{Air temperatures in the city in Poland}

The biological stability of water is defined as the lack of tendency for secondary microbial growth [9]. Water in fountains should also be biologically stable water. Considering only the Legionella bacteria - there is a danger that on hot days in the fountains there may be conditions favourable to their development due to raising the water temperature. In addition, it should be noted that long-lasting high air temperatures affect the temperature of 
the surface water (source of drinking water) and the temperature of the ground. As a result, the risk of rising water temperatures in the fountain itself is increasing.

Numerous climate changes are observed. Different sources [i.a. 10] indicate that some extreme phenomena (including heat waves) will increase in strength and occur more frequently. Climate models predict global warming and projections for Poland estimate a temperature rise of up to 3,5 degrees Celsius for the summer [10]. For these reasons, the scope of research has been extended to the analysis of air temperature in Krakow in recent decades. The summer of 2015 in Poland was a period of significantly high air temperatures. The end of spring of 2017 was also very hot. Figure 1 shows a graph of average monthly temperatures for a meteorological station located in Krakow for 2015 and a multi-year average (1971-2000 and 2001-2010) based on data of Central Statistical Office and Institute of Meteorology and Water Management - National Research Institute [11]. By analysing the graph, it can be seen that the average monthly air temperatures recorded in Cracow in 2015 are higher than the multi-year average in 9 months. In April, May and October were lower temperatures.

Analysis of air temperature data confirms that the warmest months in Poland are from May to September each year. For this reason, the study was conducted in July, August and September 2015 and May and June 2017.

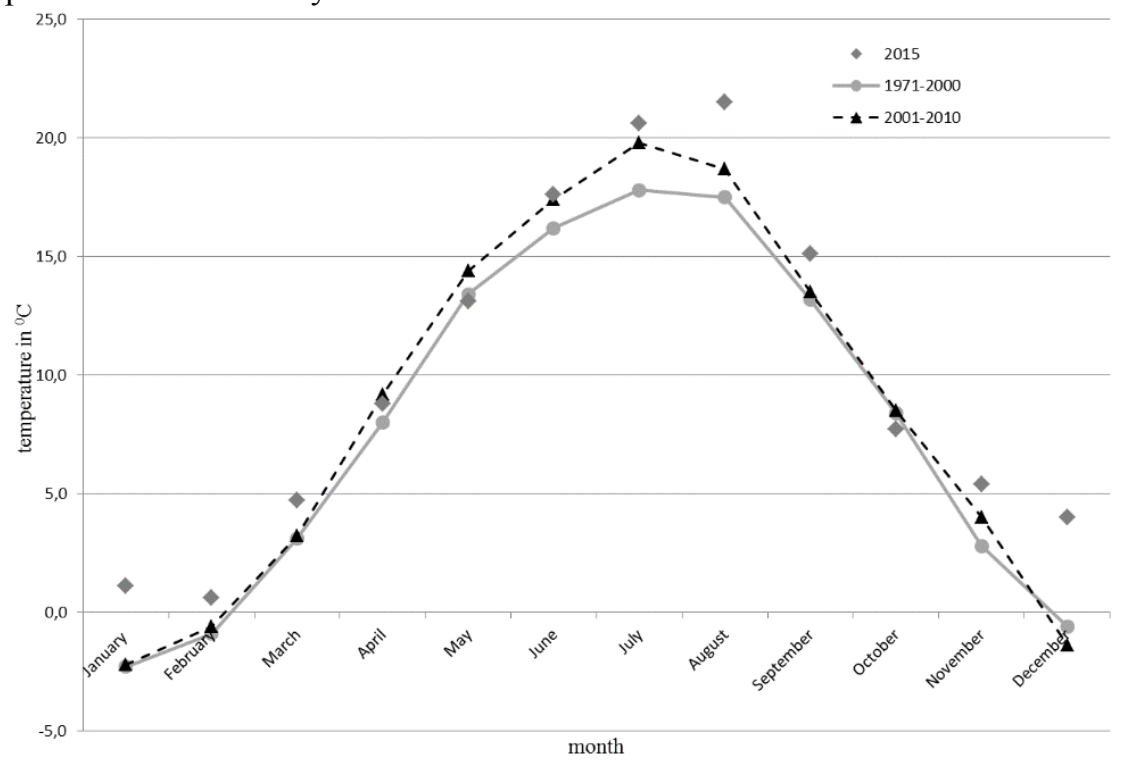

Fig. 1. Average monthly air temperatures for individual months from meteorological station in Krakow in the years 1971 - 2000, $2001-2010$ and 2015, data of Central Statistical Office and Institute of Meteorology and Water Management - National Research Institute [11] - own elaboration

\subsection{Influence of temperature on the growth of Legionella bacteria}

Dependence the survival of Legionella bacteria and the water temperature was repeatedly investigated (among others [12-13]). The literature provides narrower or wider temperature ranges suitable for the growth of these bacteria. This depends, inter alia, on the conditions they concern (natural or laboratory).

Under laboratory conditions, Legionella bacteria grow in the range of $15 \div 43^{\circ} \mathrm{C}$, with optimum $36^{\circ} \mathrm{C}$ [14]. In developed recommendations [15] as the optimal growth temperature, but in natural conditions, the range of $32 \div 42^{0} \mathrm{C}$ is mentioned. Research [12] suggests a range of temperatures $32 \div 42^{\circ} \mathrm{C}$ with an optimum of $37^{\circ} \mathrm{C}$ for the multiplication 
of naturally occurring L. pneumophila in tap water. In the publication [1] it appears that these bacteria settle in the network of utility water at temperatures of $20 \div 50^{\circ} \mathrm{C}$. According to [14] Legionella bacteria colonize often water distribution systems at temperatures between $20 \div 50^{\circ} \mathrm{C}$ and thus within the same range as in the previous work. In recommendations [15] it is stated that the temperature range of $20 \div 45^{\circ} \mathrm{C}$ is one of the factors contributing to the occurrence and proliferation of artificial reservoirs of water.

According to [12], little or no growth of L. pneumophila was observed at $25^{\circ} \mathrm{C}$. In turn, according to [16], little, if any, increase in number of Legionella bacteria is noted below $20^{\circ} \mathrm{C}$. Other authors [15] indicate that at temperature less than $20^{\circ} \mathrm{C}$ Legionella bacteria do not multiply, but survive for a long time. This fact has been demonstrated in studies [17], where it was found that at $5^{\circ} \mathrm{C}$ in tap water these bacteria can survive for more than 299 days. For these reasons, it is suggested that temperatures below $25^{\circ} \mathrm{C}$ be recommended for cold water storage and distribution, stating that it would be ideal to be below $20^{\circ} \mathrm{C}$ [16]. However, recent studies on mutant strains of Legionella bacteria [18] have shown that these bacteria may also grow at temperatures below $20^{\circ} \mathrm{C}$ under certain conditions.

\section{Materials and methods}

The study was conducted in two phases: summer 2015 and late spring 2017. In the first stage, water temperatures in selected fountains were measured in one or two series at different times of the day. The results were then compared with the preferred temperature range for the growth of Legionella bacteria. In the second stage the temperature was measured in one fountain, but increasing the frequency of measurements during the day. The research was conducted in different years in search of period of possibly high air temperatures.

Both the selection of the public fountains under study and the months in which the research was conducted were targeted. The research was conducted in the hottest months of the year, i.e. in May, June, July, August and September.

Public fountains were surveyed in Cracow. The work was carried out by the Cracow University of Technology as part of a research project. The research has deliberately chosen fountains located in the very centre of the city which is a popular destination for many tourists. On hot days the fountains located most often in sunny places are an oasis for travellers seeking refreshing.

The number of measuring points was adjusted to the size of the fountain basin and its geometry, so that the average temperature could be representative of the fountain, and the individual measurements provided complete information about the water temperature. Measurement points were evenly located in the basin of the fountain. Fountains with simple geometric shapes of the basin (rectangle, circle, oval) were studied. Sometimes, if temperature of water were aligned in previous tests, the number of measurement points was reduced due to difficulty in accessing them.

Fountains number 1 and 2 flow in closed loop. Fountain number 3 has an open circuit, but the stop time in the fountain's basin is long enough to allow the water to warm up in it. Studies in fountain number 3 have been added for comparative purposes.

In the first stage of the study, one or two series were performed at intervals of approximately 60 minutes. In the second stage, the number of series of tests performed in one day was increased. During each series of tests were recorded: water temperature in the fountain basin at several measurement points, air temperature and air humidity.

Water temperature tests were carried out using a KT-300 digital thermometer. The thermometer resolution was $0.1^{\circ} \mathrm{C}$ and its accuracy was $\pm 1^{\circ} \mathrm{C}$. Air temperature and humidity were recorded on the WS-9400 weather station. 


\section{Results and discussion}

Results of water temperature tests in the fountains of the first stage of the tests are presented in Tables 1,2 and 3. In each tabulation prepared for each of the examined fountains, there are the date of measurements, the measurement of the basic parameter, i.e. the water temperature expressed in degrees Celsius and name of measurement points.

Table 1. Results of the water temperature test in the fountain number 1 in Krakow in 2015

\begin{tabular}{|c|c|c|c|c|}
\hline \multirow{2}{*}{ Date / Measurement point } & \multicolumn{4}{|c|}{ Temperature of water [ $\left.{ }^{0} \mathrm{C}\right]$} \\
\cline { 2 - 5 } & $22 / 07$ & $7 / 08$ & $20 / 08$ & $30 / 09$ \\
\hline 1 & 24,0 & 24,1 & 17,9 & 11,1 \\
\hline 2 & 24,1 & 24,2 & 18,0 & 11,1 \\
\hline 3 & 24,1 & 24,1 & 18,0 & 11,1 \\
\hline 4 & 24,0 & 24,1 & 18,1 & 11,0 \\
\hline 1 & 24,8 & 24,7 & & \\
\hline 2 & 24,8 & 24,7 & $-*$ & $-*$ \\
\hline 3 & 24,8 & 24,8 & & \\
\hline 4 & 24,8 & 24,8 & & \\
\hline
\end{tabular}

* no data

Table 2. Results of the water temperature test in the fountain number 2 in Krakow in 2015

\begin{tabular}{|c|c|c|c|c|}
\hline \multirow{2}{*}{ Date / Measurement point } & \multicolumn{4}{|c|}{ Temperature of water [ $\left.{ }^{0} \mathrm{C}\right]$} \\
\cline { 2 - 5 } & $22 / 07$ & $7 / 08$ & $20 / 08$ & $30 / 09$ \\
\hline 1 & 23,8 & 24,5 & 21,1 & 11,7 \\
\hline 2 & 23,8 & 24,5 & 21,1 & 11,7 \\
\hline 3 & 23,8 & 24,5 & 21,3 & 11,7 \\
\hline 4 & 23,9 & 24,5 & 21,3 & 11,7 \\
\hline 5 & 23,9 & 24,5 & 21,3 & 11,7 \\
\hline 6 & 23,8 & 24,5 & $-*$ & 11,7 \\
\hline 7 & 23,9 & 24,5 & 21,2 & 11,7 \\
\hline 1 & 24,1 & 24,7 & & \\
\hline 2 & 24,1 & 24,7 & & $-*$ \\
\hline 3 & 24,1 & 24,7 & & \\
\hline 4 & 24,2 & 24,8 & & \\
\hline 5 & 24,2 & 24,8 & & \\
\hline 6 & 24,2 & 24,7 & & \\
\hline 7 & 24,2 & 24,7 & & \\
\hline & & \multicolumn{2}{|c|}{} & \\
\hline
\end{tabular}

\footnotetext{
* no data
}

If the name of the measurement point in the statement occurs twice, it means that two series of tests were carried out at a spacing of approximately 60 minutes on a given day. 
The air temperature during research tests ranged from 13 to 32,2 degree Celsius. The air humidity was from $34 \%$ up to $52 \%$.

Based on the research (first stage) it can be stated that the water temperatures in each fountain were aligned. Usually this difference was $0.1 \div 0.2^{0} \mathrm{C}$, although there were measurement series in which there were no differences in the measurements. Such results may indicate, among other things, the good mixing of water in fountains. In the case of fountain number 3 there is a greater temperature difference, but these are the temperatures measured in two different basins - the lower and the upper.

Table 3. Results of the water temperature test in the fountain number 3 in Krakow in 2015

\begin{tabular}{|c|c|c|}
\hline \multirow{2}{*}{ Date / Measurement point } & \multicolumn{2}{|c|}{ Temperature of water $\left[{ }^{0} \mathrm{C}\right]$} \\
\cline { 2 - 3 } & $7 / 08$ & $20 / 08$ \\
\hline 1 & 25,1 & 18,4 \\
\hline 2 & 25,1 & 18,4 \\
\hline 3 & 25,2 & 18,4 \\
\hline 4 & $-*$ & 20,6 \\
\hline 5 & $-*$ & 20,7 \\
\hline
\end{tabular}

\footnotetext{
* no data
}

In the second stage, the daily temperature distribution was measured in warm days for fountain 2. The number of measurement series varied within days, with an interval of 30 minutes to 3 hours. The water temperature in each of the measurement series was also aligned. The differences were up to $0.2^{\circ} \mathrm{C}$, or none at all. The only exception was the measurement series, where differences were up to $0.4^{0} \mathrm{C}$ (Figure 2 - series: 14,00). Probably the cause of this phenomenon was turning off the nozzle for two hours. Figure 2 shows the results of several measurement series from one day of measurements.

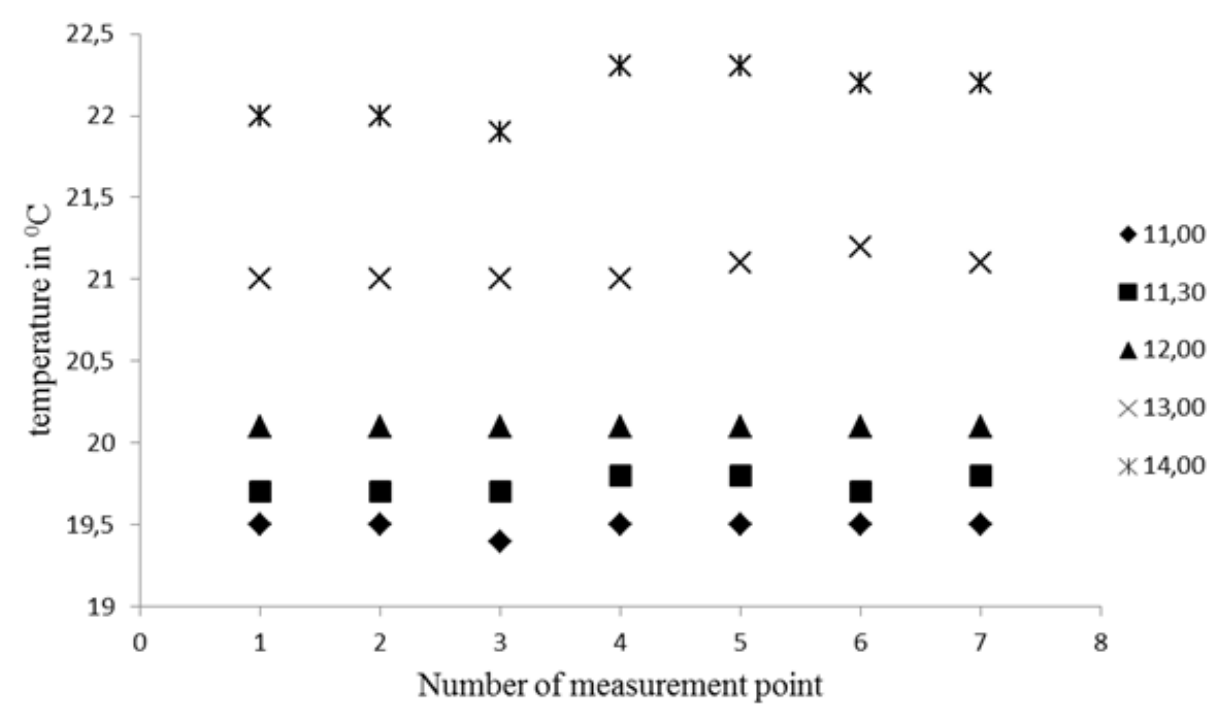

Fig. 2. Temperature of water in fountain's basin for different measurement points in five series of test during spring 2017 (30.05.2017) 


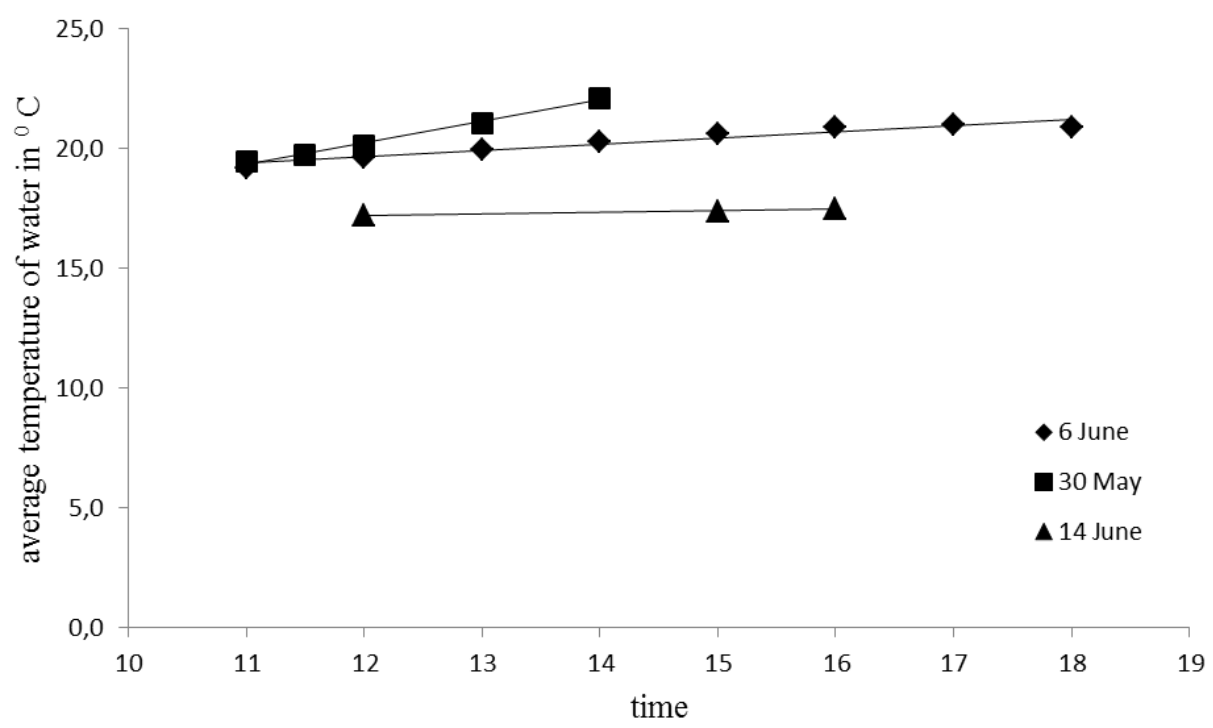

Fig. 3. Average temperature of water in fountain's basin in different days of measurement series during spring 2017

Figure 3 shows the distribution of the average water temperature in the fountain basin in daily hours on different days. It can be observed that there is a linear increase in water temperature.

In most of the first stage measurements, the water temperature in the fountains was above $20^{\circ} \mathrm{C}$, so above the temperature at which the Legionella bacteria are in hibernation state [19]. In the second stage the temperature fluctuated from $17.2^{0} \mathrm{C}$ to $22.3^{0} \mathrm{C}$. In none of the stages, however, there was no temperature higher than $26^{\circ} \mathrm{C}$. The highest temperature recorded was $25.2^{\circ} \mathrm{C}$.

It can therefore be stated that, despite the high temperature of the air, which has persisted for a long time, there was no significant increase in the water temperature in the fountains (above $26^{\circ} \mathrm{C}$ ) during the measurements. However, it may be disturbing that the water temperature was in many cases above $20^{\circ} \mathrm{C}$. According to [16] below $37^{\circ} \mathrm{C}$ the reproduction rate of these bacteria decreases and below $20^{\circ} \mathrm{C}$ there is no growth or little. At low temperatures Legionella bacteria can survive for a very long time (according to [17] up to almost 10 months at $5^{\circ} \mathrm{C}$ ). Recorded temperatures indicate the possibility of presence and slow growth of these bacteria.

While studies on the presence and development of Legionella bacteria in tap water or in hot water systems are common, water quality tests for fountains due to these bacteria are rare. Water temperature measurements in fountains in Poland were also conducted by [6] in Poznan and their results are consistent with those presented in the article in Krakow. The highest recorded water temperature in Poznan in spring was 17.9 degrees Celsius (June) and in summer was 22.2 degrees Celsius (July). These measurements were made in the morning, so the temperature during the day could increase significantly. In the presented results in fountain number 2 in Krakow the average water temperature from 19.5 degrees Celsius at 11.00 rose to over 22.0 degrees Celsius at 14.00 . It can therefore be concluded that studies [6] also confirm the existence of a potential threat from the Legionella bacteria due to the occurring water temperature in the fountains. It should be noted that in studies [6, 7] of fountain water in two large cities of Poland (Poznan and Warsaw), the presence of mesophilic bacteria was found in which Legionella could be present. 
In another studies [20] among the samples of water with a temperature in the range of over 20 degrees and below 50 degrees Celsius, taken from fountains, swimming pools, cooling and heating systems, in $12 \%$ Legionella bacteria were detected.

\section{Conclusion}

Water in fountains is usually disinfected and can be considered as safe. However, there are various breakdowns in the case of urban fountains, and there may be a danger of excessive development of Legionella bacteria due to high temperature of water. As a consequence, secondary water pollution may even lead to outbreaks of legionellosis in the spring and summer. Therefore, the temperature and quality of water surrounding us in urban space is also very important.

Every fountain is different. Differences include the shape of the basin, its dimensions or the volume of the underground tank. It seems reasonable to require at least one single test of water temperature in fountain basin during period of high air temperatures to determine whether there is a risk of inordinate growth of Legionella bacteria. If the study confirms such a threat, it is extremely important to introduce additional technical safeguards which will protect water in fountains.

\section{References}

1. W. Magdzik, D. Naruszewicz - Lesiuk, A. Zieliński, Diseases of infectious and parasitic diseases - epidemiology and prevention, $\alpha$ - Medica Press Bielsko - Biała, $154-159$ (in polish) (2007)

2. Rozporządzenie Ministra Zdrowia z dnia 13 listopada 2015 r. w sprawie jakości wody przeznaczonej do spożycia przez ludzi, Dz.U.2015, 1989 (2015)

3. Rozporządzenie Ministra Zdrowia z dnia 29 marca 2007 r. w sprawie jakości wody przeznaczonej do spożycia przez ludzi, Dz. U. 2007 No 61, 417 (2007)

4. Rozporządzenie Ministra Zdrowia z dnia 9 listopada 2015 r. w sprawie wymagań, jakim powinna odpowiadać woda na pływalniach, Dz. U. 2015, 2016 (2015)

5. J. Sperzyńska, M. Michałkiewicz in Dymaczewski Z., Jeż-Walkowiak J., Urbaniak A. Water supply and water quality, Poznań, 385 - 394 (in polish) (2016)

6. M. Michałkiewicz, A. Szumigała, Technology of water, 38, number 6, 83 - 91 (in polish) (2014)

7. E. Miaśkiewicz - Pęska, D. Dąbrowska, Installation market, no. 4, 106 - 109 (in polish) (2016)

8. J. Bąk in Z. Dymaczewski, J. Jeż-Walkowiak, A. Urbaniak Water supply and water quality, Poznań, 235 - 246 (in polish) (2016)

9. J. Nawrocki, S. Biłozor - editors, Water treatment. Chemical and biological processes, Scientific Publishing House, PWN (in polish) (2000)

10. Z.W. Kundziewicz, P. Kowalczak, Climate change and their effects, KURPISZ S.A. (in polish) (2008)

11. Central Statistical Office and Institute of Meteorology and Water Management National Research Institute, Environment (2016)

12. R.B. Yee, R.M. Wadowsky, R.M., Appl. Environ. Microbiol., 43, No.6, 1330 - 1334 (1982)

13. A. Ohno, N. Kato, K. Yamada, K. Yamaguchi, Appl. Environ. Microbiol., 69, No. 5, $2540-2547(2003)$ 
14. K. Botzenhart, Legionella in Guidelines for drinking - water quality. Second edition. Addendum. Microbiological agents in drinking water, WHO Geneva, 40 - 69 (2002)

15. B. Krogulska, R. Matuszewska, D. Maziarka, A. Krogulski, M. Szczotko, M. Bartosik, Zalecenia dotyczące ograniczenia występowania zanieczyszczeń mikrobiologicznych, w tym bakterii z rodzaju Legionella, w systemach wody technologicznej/chłodniczej i w sanitarnych instalacjach wody ciepłej w zakładach przemysłowych, National Institutes of Public Health, The National Institute of Hygiene, Warsaw (2013)

16. J. Bartram, Y. Chartier, J.V. Lee, K. Pond, S. Surman - Lee, (edition), Legionella and the prevention of legionellosis, WHO (2007)

17. S.C. Hsu, R. Martin, B.B. Wentworth, Appl. Environ. Microbiol., 48, no. 4, 830 - 832 (1984)

18. M. Sodeberg, O. Rossier, N. Cianciotto, J. Bacteriol., 186, 3712 - 372 (2004)

19. E. Szewczyk, (scientific editor), Bacteriological diagnostics, PWN, Warsaw (in polish) (2013)

20. A. Bešić, Z. Obradović, A. Dautbegović, A. Obradović, Journal of Health Science, 7, no $1,50-58(2017)$ 